\title{
Policy measures for reducing aquifer depletion in a context of climate change: the case of the coastal area of Cap-Bon (Tunisia)
}

\author{
Ali Chebil ${ }^{\star}$, Taher KahiL ${ }^{\star \star}$, Bilel Oueslati ${ }^{\star \star \star}$ \\ DOI: $10.30682 / \mathrm{nm} 1804 \mathrm{c}$ \\ Jel codes: C61, Q25, Q54
}

\begin{abstract}
Groundwater resources are critically important for irrigated agriculture in Tunisia. However, excessive irrigation extractions where groundwater is slowly renewed are causing a widespread depletion of the aquifer systems, with the impacts of climate change expected to further exacerbate this problem. These circumstances call for the development of methodologies and analyses that can support the design of sustainable groundwater management policies. This paper presents a hydro-economic mathematical programming model that is used to evaluate the effects of different policy measures for reducing aquifer depletion in the Cap-Bon region of Tunisia. Three policies have been evaluated: a quota defining the maximum quantity of groundwater extractions, environmental taxation, and supply expansion with subsidized desalinated seawater. Overall, results highlight the economic and social tradeoffs among these different policy choices and the challenges facing the implementation of sustainable groundwater management in Tunisia. More specifically, results show the advantages of using subsidized desalinated seawater compared to the other two policy alternatives in terms of the value of agricultural production, farmers' profits, and employment, despite of its sizeable budgetary burden.
\end{abstract}

Keywords: Climate change, Groundwater depletion, Mathematical programming, Water policy measures, Tunisia.

\section{Introduction}

Irrigated agriculture plays an important role in securing global food production, and sustaining locally rural livelihoods and ecosystems. It is estimated that $17 \%$ of agricultural lands are irrigated, yet they account for $40 \%$ of the global food production (Abdullah, 2006). At the same time, irrigation is the main user of water resources worldwide, and especially in arid and semi- arid regions (Shiklomanov, 2000). On the other hand, groundwater represents the world's largest freshwater resource and is critically important for irrigated agriculture (Koundouri, 2004). However, depletion is widespread in large groundwater systems in both semi-arid and humid regions of the world (Konikow, 2011). Excessive extraction for irrigation where groundwater is slowly renewed is the main cause of the depletion, and

* Institut National de Recherches en Génie Rural, Eaux et Forêts (INRGREF), Ariana, Tunisia.

** International Institute for Applied Systems Analysis (IIASA), Laxenburg, Austria.

*** Faculty of Economics and Management of Tunis, Tunisia.

Corresponding author: chebila@yahoo.es. 
climate change has the potential to exacerbate the problem in some regions (Wada et al. 2012).

Tunisia is one of the countries in the world least well-endowed with water resources. These resources are scarce and their quality is degraded. Therefore, Tunisia has become a water stressed country in terms of per capita renewable water resources, with only $400 \mathrm{~m}^{3}$ per capita, which is well below the global average of $1000 \mathrm{~m}^{3}$ per capita (WB, 2014). Water problems in Tunisia are linked to the country's shrinking water supply, and to the exceedingly high and growing water demand, mainly in the agricultural sector (that already uses $85 \%$ of total water withdrawals) (ITES, 2014). With most available surface waters already polluted, groundwater resources are now being heavily overexploited. The challenges posed by non-sustainable groundwater use are most notable in Tunisia, with extractions significantly exceeding the natural recharge. For instance, the total number of aquifers in Tunisia is about 273 , of which 71 are overexploited at an average rate of $146 \%$ (i.e. $46 \%$ higher than their natural recharging rate), with total groundwater depletion amounting to about $650 \mathrm{Mm}^{3}$ per year (ITES, 2014; TICET, 2009).

Several policy measures have been progressively introduced and implemented to address groundwater depletion in Tunisia during recent decades (Frija et al., 2015). This includes the requirement for an authorization for the pumping of groundwater resources; the classification of some overused aquifers as "exclusion areas", where the exploitation of groundwater has to be strictly authorized by government administrations; and the classification of other more critical aquifers as "prohibited areas", where all types of new wells are strictly prohibited and any infraction is punished by law. Despite these efforts, groundwater policies in Tunisia are considered to be insufficient (Faysse et al., 2011). For instance, the use of economic instruments to deal with groundwater depletion remains limited, with the main economic instrument used is related to the National Program for Water Savings, which offers farmers subsidies for investing in irrigation-saving technologies (Bachta and Elloumi, 2005).
The majority of studies conducted in Tunisia about groundwater management policies are thus far descriptive (Faysse et al., 2011, Frija et al., 2015, Ghazouani and Mekki 2016; Elloumi 2016), despite the valuable recommendations provided to address groundwater depletion. Mahdi and Sghaier (2017) used the theory of information asymmetry to investigate the incentive regulation for public irrigation water services managed by irrigation agencies in the south of Tunisia, which could be considered as the only study tried to introduce quantitative approach into groundwater management. Our paper aims to provide a quantitative comparative analysis of the effectiveness of different policy measures (water use quota, environmental tax, and supply expansion with subsidized desalinated seawater) to control groundwater extractions under current and future climate conditions in Tunisia, using a hydro-economic mathematical programming model. To the best of our knowledge, there are no studies in the literature that used a hydro-economic modeling approach to evaluate groundwater policies in a context of climate change in Tunisia.

Our analysis focuses on an intensive irrigated area in Northeastern Tunisia, the Cap-Bon region. This region is one of the most productive agricultural areas in Tunisia, produces most of country's exported crops, and provides considerable employment opportunities. Intensive irrigation activities in this region have caused a substantial increase of groundwater extractions, and consequently the depletion of groundwater resources along with the degradation of their quality. The sustainability of groundwater-based irrigation in the Cap-Bon region has become a real challenge for decision makers (Frija et al., 2015, Elloumi, 2016).

The remainder of the paper is organized as follows. First, a literature review on the available policy measures to control groundwater extractions is conducted in Section 2. Section 3 describes the study area and data sources, followed by the explanation of the modeling framework and scenarios of groundwater management in Section 4. Section 5 discusses the results. Finally, Section 6 concludes with the summary and policy implications. 


\section{Literature review: policy measures to con- trol groundwater extractions}

This section reviews a number of studies in the literature that investigated the use of policy measures to regulate groundwater extractions and reduce aquifer depletion. A large bundle of policy measures are proposed in the literature for managing groundwater resources (Koundouri, 2004). The most commonly used measures are based on restricting water pumping by establishing quotas that define a maximum quantity of water extraction or a minimum water table level. The advantage of water quotas is that they allow equity issues to be taken into consideration and promote transparent reallocation of water (Johansson et al., 2002; Blanco-Gutiérrez et al., 2010). However, some studies in the literature indicate that water quotas are less efficient compared to other measures, too inflexible to adapt to changing climate and market conditions, and associated with high implementation costs (Zekri, 2008; Molle, 2009; Esteban and Dinar, 2013). An alternative to water quotas is the buyback of pumping permits by the public authorities. This measure has the advantage of permanently reducing extractions and does not harm farmers' income, as they are compensated, but it has both a high public budgetary cost and significant impacts on the rural economy (Carmona et al., 2011).

Public policies that provide different type of subsidies to reduce groundwater extractions, such as subsidies for investments in improved irrigation technology or the use of alternative water sources, are often viewed as effective and politically-feasible control measures. Perry and Hellegers (2012) show that, contrary to widespread expectations, subsidized improved irrigation technology in Yemen triggered the expansion of irrigated areas and the shift towards more profitable and water-intensive crops, which increased groundwater extractions. Similar results on the effects of subsidized improved irrigation technology on groundwater extractions are found in the United States (Pfeiffer and Lin, 2014). Martínez-Granados and Calatrava (2014) analyze the opportunity to reduce aquifer depletion in Southeast Spain with the use of desalinated seawater and find that desalinated water may not be effective to reduce groundwater extractions if farmers have to bear the full desalination cost and no subsidy is provided. Zekri et al. (2014) evaluate the cost-effectiveness of managed aquifer recharge using treated wastewater in Oman, which seems to be an appealing measure from an economic perspective if groundwater is used for drinking purposes, but not for irrigation because of the high cost of wastewater treatment.

Tax instruments that penalize the use of groundwater or the decrease in the water table level are also policy measures commonly analyzed in the literature for their water-saving potential and their reputation as appropriate cost-recovery mechanisms (Sorensen and Herbertsson, 1998). In most countries around the world, farmers using groundwater usually pay for the investment and operating costs of water pumping but they do not pay any additional fee (Berbel et al., 2007). Thus, the financial costs of groundwater pumping are fully recovered, but resource and environmental costs are usually not included, causing the depletion of aquifers (Garrido and Calatrava, 2010). From a theoretical point of view, a tax instrument is an effective policy measure to control the level of groundwater extractions (Esteban and Dinar, 2013). However, many empirical applications conclude that irrigation water demand is very inelastic in the short term, at least for low water prices or reduced water availability (Wheeler et al., 2008), and that the taxation of groundwater extractions can have a significant impact not only on farmers, but also on the whole agricultural sector and the rural economy (Scardigno et al., 2014).

The last two decades witnessed the upsurge of new water management measures based on the involvement of stakeholders, including market-based instruments and voluntary agreements. Market-based instruments, such as water tradable permits, in which users are assigned a quantity of water (permits) and they have the option to sell them to or to buy from other users (private market rules) are efficient mechanisms because the market establishes the optimal prices and quantities (Easter et al., 1999). However, one challenge facing the implementation of such measures is the necessity of having well-func- 
tioning water institutions to manage the rights and setup the rules (Skurray and Pannell, 2012). On the other hand, the voluntary agreements which users undertake by themselves to reduce the extractions and protect the resource are efficient instruments, but usually require the creation of incentives for farmers to collaborate and monitoring costs to prevent cheating (Madani and Dinar, 2012; Esteban and Albiac, 2012).

\section{Study area and data sources}

The Cap-Bon region is located in Northeastern Tunisia (Figure 1). Its climate is semiarid with an average annual precipitation of $420 \mathrm{~mm}$ (INM, 2005). Water used in the region originates from four sources: surface water in local dams, groundwater, treated wastewater, and surface water transfer coming from the Medjerda River in Northern Tunisia. Only surface water and groundwater resources are used for irrigation. However, the reduction of surface water allocation to irrigated agriculture in order to meet the growing demand of competing uses is increasing irrigation pressures on groundwater resources.
At present, irrigation in the Cap-Bon region extends over 26,000 ha, which represents $2.6 \%$ of the total agricultural area in Tunisia. It contributes with about $35 \%$ to the country's agricultural production (ITES, 2014). Irrigation in the Cap-Bon region uses about $74 \mathrm{Mm}^{3}$ of water, of which $54 \mathrm{Mm}^{3}$ are groundwater resources from the East Coast aquifer, $8.5 \mathrm{Mm}^{3}$ are surface water resources from local dams, and 11.5 $\mathrm{Mm}^{3}$ are surface water resources coming from the Medjerda water transfer project (DGGREE, 2012).

For the purpose of the present paper, our analysis focuses on the coastal irrigated area (highlighted in red with dashed lines in Figure 1), which covers $15 \%$ (or 3,930 ha) of the total irrigated area in the Cap-Bon region, which well represents the cropping pattern and farming practices in the whole region. Data used in this study has been collected from several primary and secondary data sources. A survey was conducted during 2011 and 2012 with 150 farmers spread across the study area. The data set in table 1 includes revenues and costs of crops, crop area, labor use, yields, water use, and crop prices. The data set also includes information on

Figure 1 - Map of the Cap-Bon region.

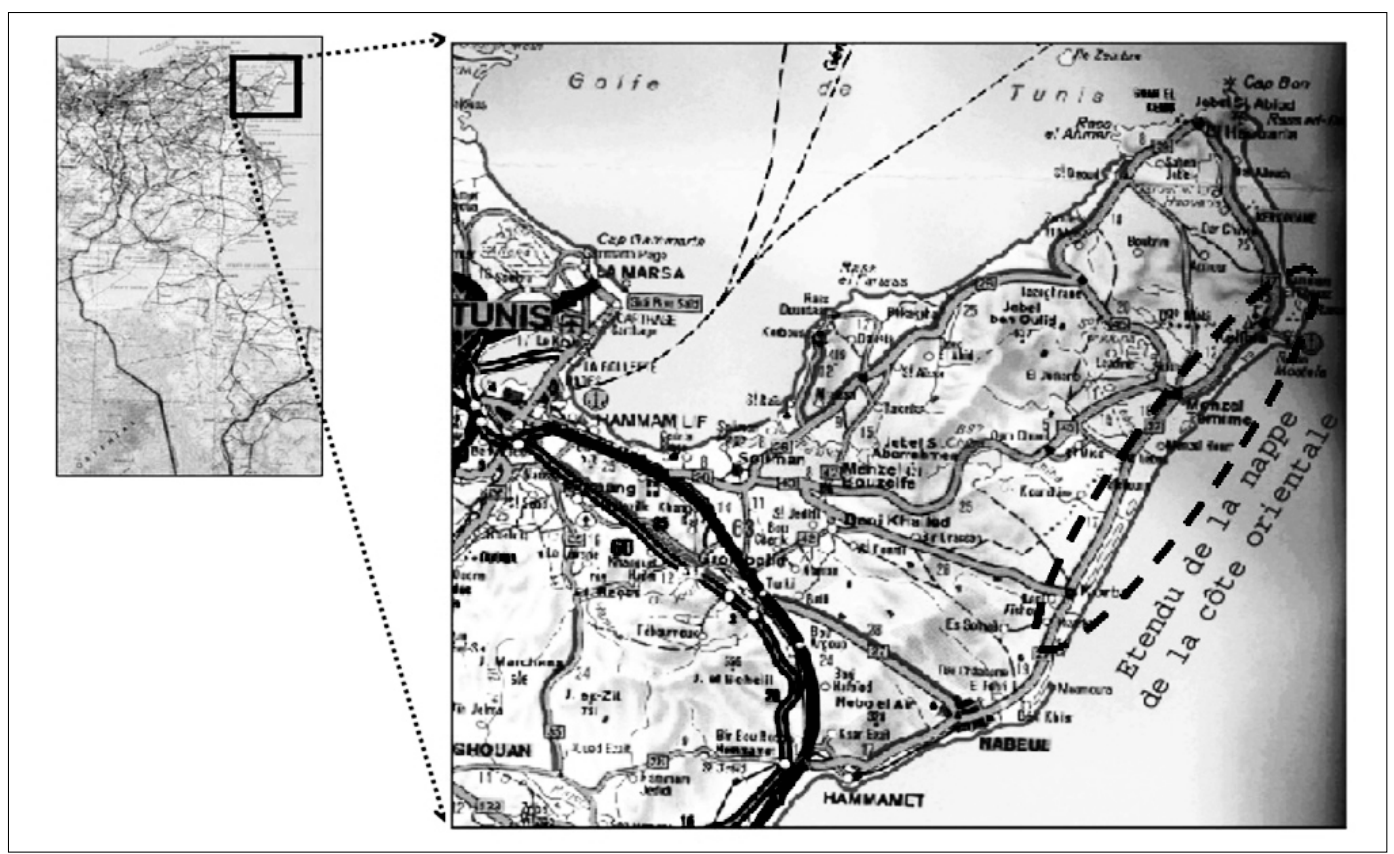


Table 1 - Crop area, water use and economic data in the study area.

\begin{tabular}{|l|c|c|c|c|c|c|c|c|}
\hline \multicolumn{1}{|c|}{ Crops } & $\begin{array}{c}\text { Land in } \\
\text { production } \\
(\mathrm{ha})\end{array}$ & $\begin{array}{c}\text { Water } \\
\text { use } \\
\left(\mathrm{m}^{3} / \mathrm{ha}\right)\end{array}$ & $\begin{array}{c}\text { Labor } \\
\text { use } \\
(\text { day/ha) }\end{array}$ & $\begin{array}{c}\text { Yield } \\
(\text { T/ha })\end{array}$ & $\begin{array}{c}\text { Crop } \\
\text { Price } \\
(d t / T)\end{array}$ & $\begin{array}{c}\text { Revenue } \\
(d t / h a)\end{array}$ & $\begin{array}{c}\text { Cost of } \\
\text { production } \\
(d t / h a)\end{array}$ & $\begin{array}{c}\text { Gross } \\
\text { margin } \\
(d t / h a)\end{array}$ \\
\hline Tomato & 865 & 4,500 & 109 & 80 & 127 & 10,160 & 5,079 & 4,766 \\
\hline Pepper & 395 & 6,745 & 80 & 13 & 500 & 6,500 & 4,253 & 1,775 \\
\hline Strawberry & 564 & 7,841 & 57 & 30 & 1,750 & 52,500 & 28,551 & 23,401 \\
\hline $\begin{array}{l}\text { Other summer } \\
\text { vegetables } \\
\text { (OVS) }\end{array}$ & 56 & 4,000 & 52 & 30 & 400 & 12,000 & 8,330 & 3,390 \\
\hline Cabbage & 88 & 3,802 & 103 & 70 & 250 & 17,500 & 5,022 & 12,212 \\
\hline $\begin{array}{l}\text { Other winter } \\
\text { vegetables } \\
\text { (OVW) }\end{array}$ & 1,166 & 3,500 & 58 & 45,000 & 0.3 & 13,500 & 3,350 & 9,905 \\
\hline Grenade & 144 & 2,500 & 23 & 11 & 650 & 7,150 & 1,297 & 5,678 \\
\hline Grapes & 22 & 6,000 & 76 & 11 & 1,350 & 14,850 & 1,622 & 12,808 \\
\hline Citrus & 72 & 8,892 & 27 & 40 & 500 & 20,000 & 7,254 & 12,124 \\
\hline $\begin{array}{l}\text { Other fruit } \\
\text { trees (OFT) }\end{array}$ & 101 & 4,500 & 121 & 20 & 650 & 13,000 & 4,285 & 8,400 \\
\hline Fodder & 457 & 3,000 & 21 & 350 & 8 & 2,800 & 1,361 & 1,229 \\
\hline Total & 3,930 & & & & & & & \\
\hline
\end{tabular}

Source: Benalaya et al. (2015). Note: One Tunisian Dinar (dt) is equivalent to 0.54 US Dollars in 2014.

the water prices in the study area, which amount to $0.07 \mathrm{dt} / \mathrm{m}^{3}$ for surface water diversion and 0.3 $\mathrm{dt} / \mathrm{m}^{3}$ for groundwater pumping. These data are obtained from a series of surveys within the framework of the project "Virtual water and food security in Tunisia, 2012-2015" (Benalaya et al., 2015).

The selected irrigated area uses water from two sources: surface water that amounts to 11.2 $\mathrm{Mm}^{3}$ per year $(60 \%$ of total water use) originating from both the Medjerda water transfer project and local dams, and groundwater extractions from the East Coast aquifer amounting to $7.4 \mathrm{Mm}^{3}$ per year $(40 \%$ of total water use). Groundwater extractions are well above the natural recharge of the aquifer, estimated to be around $0.24 \mathrm{Mm}^{3}$ per year. The intensive pumping for irrigated agriculture in this area has caused considerable water table level drawdown (about $5 \mathrm{~m}$ below the sea level), and seawater intrusion (with salinity concentration of water between 5 and $8 \mathrm{~g} / \mathrm{l}$ ) (Chebil et al., 2014).

\section{Methodology and scenarios}

\subsection{Modeling framework}

The analysis of the policy measures to reduce aquifer depletion is conducted using a hydro-economic mathematical programming model. This model follows a similar approach used by Kahil et al. (2015a, 2015b and 2016a), which integrates hydrologic, agronomic and economic components into a unified modeling framework for a comprehensive policy analysis. This type of models simulates land and water allocation among crops and computes several economic indicators (value of agricultural production, production costs, farmers' profits, public expenditures and collections, cultivated area, and agricultural employment). The objective of our model is to maximize farmers' profits in the study area, subject to various technical and resource constraints. A Leontief production function technology is assumed with fixed input and output prices, where farmers are price takers. 
The mathematical formulation of the model is as follows:

$\operatorname{Max} \pi=\left[\left(\sum_{i}\left(P_{i} \cdot Y_{i}-\right.\right.\right.$ Prodcosts $\left.\left.\left._{i}\right) \cdot X_{i}\right)-P_{s w} \cdot S W-P_{g w} \cdot G W\right]$

subject to

$$
\sum_{i} X_{i} \leq \text { Landavail }
$$

$\sum_{i} W_{i} \cdot X_{i} \leq$ Wateravail

$\sum_{i} L_{i} \cdot X_{i} \leq$ Laboravail

$X_{i} \geq 0$

where equation (1) is the objective function of farmers' profits from irrigation activities, which is defined by the difference between crop revenues and production costs (including water and non-water costs). This objective function is maximized subject to land use constraint (equation 2 ), water availability constraint (equation 3 ), and labor constraint (equation 4). Equation (5) is the non-negativity constraint. The parameters of the model are: $P_{i}=$ price of $\operatorname{crop} i$; $Y_{i}=$ yield of crop $i$; $P_{s w}=$ price of surface water diversion; $P_{g w}=$ cost of groundwater pumping; and Prodcosts ${ }_{i}=$ production costs other than water costs of crop $i$. Landavail is land available for crop cultivation, Wateravail is the amount of surface and ground waters available for irrigation, and Laboravail is labor availability in the region. The variables of the model are: $X_{i}=$ area of each crop $i ; S W=$ surface water diversion; and $G W=$ groundwater extractions. The solution of the model provides information on the optimal cropping pattern and associated inputs use including water and labor use, as well as the economic benefits and costs associated with the agricultural production.

The use of mathematical programming models to analyze agricultural production at regional level faces the problem of aggregation and overspecialization because farms in a region are different in terms of resources endowment, technologies, and management skills. Ideally, a regional model should include a component for every individual farm, but this is unfeasible because of the complexity of such a model.
Many approaches have been developed to solve this problem and to calibrate regional models to observed conditions such as the representative farm approach (Day, 1963), the convex combination approach (Önal and McCarl, 1991), and the positive mathematical programming (PMP) approach (Howitt, 1995).

Our model is calibrated to observed crop area using the PMP approach. The application of this approach as a mean for calibration has significantly increased during the last two decades. The main advantages of PMP compared to other approaches are the exact representation of the base conditions, lower data requirements, and a smooth response of the model to continuous changes in exogenous parameters when the model is used for analysis of policy changes. In this study, we follow the standard PMP approach to calibrate our model to observed crop area, which involves a two-step procedure for implementation (Fragoso and Marques, 2015). In the first step, the model described in equations (1) to (5) is bounded by observed crop area by introducing a set of calibration constraints. In the second step, dual values associated with the calibration constraints are used to calculate calibration parameters, which represent the marginal cost coefficients of a convex cost function, and are incorporated into the objective function (1), such that once the calibration constraints are removed, the modified model reproduces exactly the observed crop area.

\subsection{Policy and climate scenarios}

The hydro-economic model is used to assess the effects of three policy measures under two climate scenarios. The three policy measures are the following:

Policy 1: This measure aims to eliminate aquifer overexploitation, by establishing a quota that limits the maximum quantity of groundwater extractions for irrigation purposes to the natural recharge of the aquifer.

Policy 2: This measure introduces an environmental tax on groundwater extractions in order to reduce extractions up to the natural recharge of the aquifer, following the "polluter pays" principle and reflecting the full cost of water supply 
as well as the scarcity value of the resource. This measure is similar to the water pricing policy advocated by the European Water Framework Directive.

Policy 3: This measure expands the water supply for irrigated agriculture. The measure seeks to substitute non-renewable groundwater resources with subsidized desalinated seawater. Tunisia has the advantage of having a relatively long coastline which gives it easy access to this resource. Therefore, one potential solution to address the growing water scarcity in Tunisia is to invest in desalination plants.

The considered climate scenarios are the following:

Scenario 1 or current climate conditions: This scenario represents the current climate conditions in the study area.

Scenario 2 or future climate change conditions: This scenario reduces surface water availability by $10 \%$ and groundwater recharge by $30 \%$ by 2030 . This scenario is in line with the IPCC climate projections for the Mediterranean region (IPCC 2014).

\section{Results and discussion}

\subsection{Scenario 1: Current climate condition}

Table 2 and Figure 2 show the outcomes of the different policy measures under current climate conditions. In the baseline scenario (i.e. observed situation), farmers' profits amount to 32.5 Million Tunisian Dinars (Mdt). The value of agricultural production is $64.3 \mathrm{Mdt}$. The production costs other than water costs are $29 \mathrm{Mdt}$ and water costs are $3 \mathrm{Mdt}$. Irrigated area is 3,930 ha. Total water use is about $18 \mathrm{Mm}^{3}$ of which 11 $\mathrm{Mm}^{3}$ are surface water and $7 \mathrm{Mm}^{3}$ are groundwater resources (Table 2).

Results of Policy 1, that eliminates aquifer overexploitation and limits irrigation groundwater extractions to the natural recharge of the aquifer, indicate a reduction of irrigated area by $39 \%$, with water-intensive and low-value crops (e.g. pepper and fodder) removed from the production plan, and water is more efficiently used, allocating it to high-value crops (e.g. strawberry and grapes) (Figure 2). Water use is reduced by $38 \%$. Production costs and water costs are reduced by 30 and $70 \%$, respectively. The value of agricultural production falls down by $22 \%$ from $64 \mathrm{Mdt}$ in the baseline scenario to $50 \mathrm{Mdt}$ under policy 1 . Farmers' profits decrease by only $5 \%$. Labor demand is reduced by $38 \%$.

Results of Policy 2 that introduces an environmental tax on groundwater extractions indicate that the optimal environmental tax that reduces extractions up to the natural recharge of the aquifer is equal to $0.77 \mathrm{dt} / \mathrm{m}^{3}$. This policy produces almost the same outcomes of Policy 1 in terms of crop area, water use, value of agricultural production, and labor demand. However, there is a

Table 2 - Results of the policy measures under current climate conditions.

\begin{tabular}{|l|c|c|c|c|}
\hline & Baseline scenario & Policy 1 & Policy 2 & Policy 3 \\
\hline Crop area (ha) & 3,930 & 2,393 & 2,393 & 3,930 \\
\hline Total water use $\left(\mathrm{Mm}^{3}\right)$ & 18.6 & 11.4 & 11.4 & 18.6 \\
\hline $\mathrm{SW}$ use $\left(\mathrm{Mm}^{3}\right)$ & 11.2 & 11.2 & 11.2 & 11.2 \\
\hline GW use $\left(\mathrm{Mm}^{3}\right)$ & 7.4 & 0.24 & 0.24 & 0.24 \\
\hline Desalinated water use $\left(\mathrm{Mm}^{3}\right)$ & 0.0 & 0.0 & 0.0 & 7.2 \\
\hline Value of Agricultural production $(\mathrm{Mdt})$ & 64.3 & 49.6 & 49.6 & 64.3 \\
\hline Production costs (Mdt) & 28.8 & 17.8 & 17.8 & 28.8 \\
\hline Water costs (Mdt) & 3.0 & 0.9 & 1.0 & 3.0 \\
\hline Farmers' profits (Mdt) & 32.5 & 30.9 & 30.7 & 32.5 \\
\hline Public collection (Mdt) & 0.8 & 0.8 & 1.0 & -5.2 \\
\hline Labor use (days) & 266,383 & 164,874 & 164,874 & 266,383 \\
\hline
\end{tabular}


Figure 2 - Land use decision for each policy measure under current climate condition (ha).

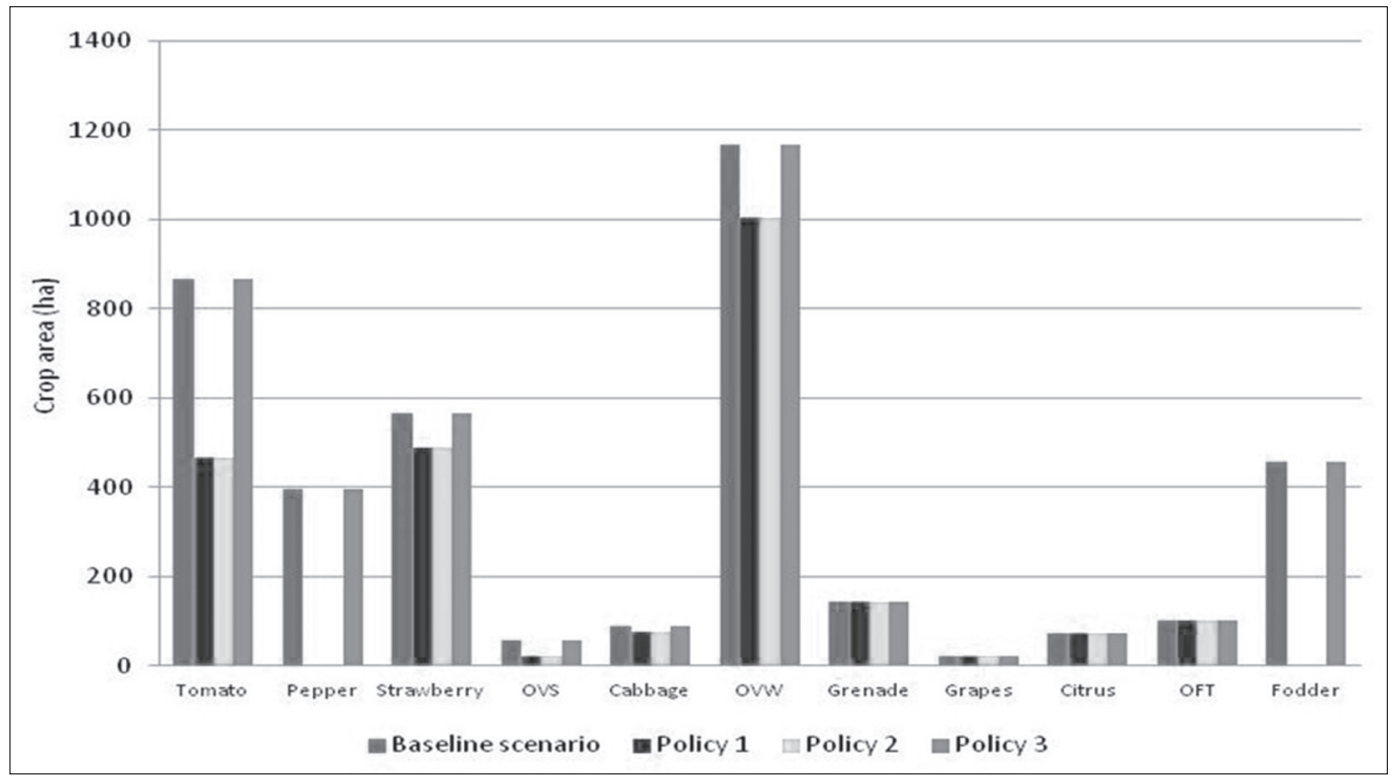

slight decrease of farmers' profits and increase of water costs. In addition, public collection of water fees rise by $24 \%$ compared to both the baseline scenario and Policy 1.

Results of Policy 3 that expands the supply of water with subsidized desalinated seawater indicate that for a full elimination of groundwater depletion in the area, the government should provide a subsidy of $0.83 \mathrm{dt} / \mathrm{m}^{3}$ (75\% of the cost of seawater desalination equal to $\left.1.15 \mathrm{dt} / \mathrm{m}^{3}\right)$. Desalinated seawater use amounts to $7.2 \mathrm{Mm}^{3}$. The outcomes of Policy 3 are similar to those of the baseline scenario in terms of crop area, total water use, value of agricultural production, production costs, water costs, famers' profits, and labor demand. However, public collection is considerably reduced because of the huge costs of desalination. Under Policy 3, the government spends $5.2 \mathrm{Mdt}$.

\subsection{Scenario 2: Future climate condition}

Results of the different policy measures for this climate scenario are shown in Table 3 and Figure 3. Results of Policy 1 that eliminates aquifer overexploitation and limits irrigation groundwater extractions to the natural recharge of the aquifer show a reduction of crop area by $43 \%$, with pepper and fodder removed from the production plan (Figure 3). Water use decreases by $41 \%$. Production costs and famers' profits are reduced by 46 and $8 \%$, respectively. The value of agricultural production falls down by $28 \%$ from $63 \mathrm{Mdt}$ in the baseline scenario to $45 \mathrm{Mdt}$ under policy 1 . Labor demand is reduced by $44 \%$.

Results of Policy 2 that introduces an environmental tax on groundwater extractions, indicate that the optimal environmental tax that reduces extractions up to the natural recharge of the aquifer is equal to $1.04 \mathrm{dt} / \mathrm{m}^{3}, 35 \%$ higher than under the current climate condition (or scenario 1). This policy produces almost the same outcomes of Policy 1 in terms of crop area, water use, value of agricultural production, and labor demand. However, there is a slight decrease of farmers' profits and increase of water costs. In addition, the public collection of water fees rises by $26 \%$ compared to baseline scenario and Policy 1.

Results of Policy 3 that expands the supply of water with subsidized desalinated seawater indicate that for a full elimination of groundwater depletion in the area, the government should provide a subsidy of $0.83 \mathrm{dt} / \mathrm{m}^{3}$ (the same 
Table 3 - Results of the policy measures under future climate condition.

\begin{tabular}{|l|c|c|c|c|}
\hline & Baseline scenario & Policy 1 & Policy 2 & Policy 3 \\
\hline Crop area (ha) & 3,772 & 2,134 & 2,134 & 3,772 \\
\hline Total water use $\left(\mathrm{Mm}^{3}\right)$ & 17.5 & 10.2 & 10.2 & 17.5 \\
\hline $\mathrm{SW}$ use $\left(\mathrm{Mm}^{3}\right)$ & 10.0 & 10.0 & 10.0 & 10.0 \\
\hline GW use $\left(\mathrm{Mm}^{3}\right)$ & 7.4 & 0.17 & 0.17 & 0.17 \\
\hline Desalinated water use $\left(\mathrm{Mm}^{3}\right)$ & 0.0 & 0.0 & 0.0 & 7.3 \\
\hline Value of Agricultural production (Mdt) & 63.4 & 45.5 & 45.5 & 63.4 \\
\hline Production costs $(\mathrm{Mdt})$ & 28.2 & 15.2 & 15.2 & 28.2 \\
\hline Water costs (Mdt) & 2.9 & 0.8 & 0.9 & 2.9 \\
\hline Farmers' profits (Mdt) & 32.2 & 29.6 & 29.4 & 32.2 \\
\hline Public collection (Mdt) & 0.7 & 0.7 & 0.9 & -5.3 \\
\hline Labor use (days) & 253,836 & 142,078 & 142,078 & 253,836 \\
\hline
\end{tabular}

Figure 3 - Land use decision for each policy measure under future climate condition (ha).

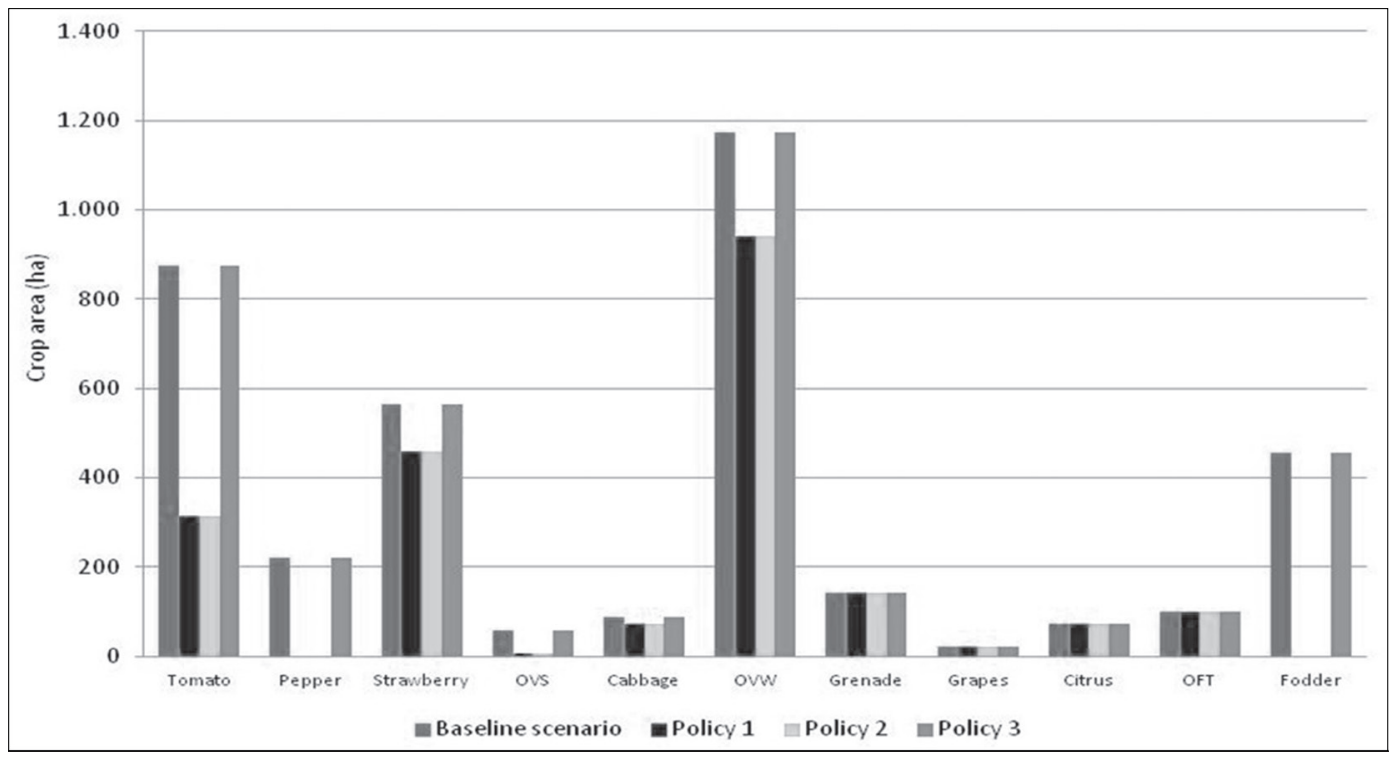

amount as under the current climate condition). Desalinated water use amounts to $7.2 \mathrm{Mm}^{3}$. The outcomes of Policy 3 are similar to those of the baseline scenario in terms of crop area, total water use, value of agricultural production, production costs, water costs, farmers' profits, and labor demand. However, public collection is considerably reduced because of the huge costs of desalination. Under Policy 3, the government spends 5.3 Mdt.

\section{Conclusions and policy implications}

Groundwater depletion is a major environmental issue in Tunisia. Intensive groundwater-based irrigation activities have increased significantly the pressures on aquifers leading to considerable groundwater table level drawdown, and water and soil quality degradation. Climate change impacts are expected to reduce water availability and increase the frequency and intensity of extreme events in Tunisia. Under 
these circumstances, water authorities in Tunisia are considering policies to reduce groundwater depletion without damaging the welfare of irrigation activities under climate change conditions. The choice of these policies requires an evaluation of their economic, environmental and social effects. This paper aims to contribute to the ongoing policy discussion about the potential policy interventions to reduce groundwater depletion in Tunisia. The paper presents the development of a hydro-economic mathematical programming model and evaluates the effects of various policy measures to reduce groundwater depletion under current and future climate conditions. The selected policy measure alternatives are a quota limiting groundwater extractions, an environmental tax on groundwater extractions, and the substitution of overexploited groundwater for desalinated seawater resources.

Results of this study indicate that establishing a quota limiting groundwater extractions, in absence of alternative substituting resources, will have large negative impacts on agricultural production under both climate scenarios, by reducing irrigated area and the value of agricultural production. In addition, employment is significantly reduced under this policy measure. These results confirm previous findings in the literature indicating that water quota, which is the mainstream policy instrument to control groundwater extractions in Tunisia, might not be very effective to address groundwater management issues and would likely be met by opposition from farmers and rural community leading to policy failure (Giannoccaro et al., 2010). An environmental tax on groundwater extractions yields similar outcomes to those of the water use quota. Its only advantage is that it generates tax revenues, but its implementation would be unfeasible from a political point of view (Kahil et al., 2016b). In contrast, the substitution of overexploited groundwater for desalinated seawater resources protects the agricultural production, farmers' profits, and employment, although the costs for the government are disproportionate compared to the other two policy alternatives. This policy measure could further gain ground in the future given the projected decreases in the costs of seawater desalination and the expected climate change impacts on conventional water resources (Ghaffour et al., 2013; Martínez-Granados and Calatrava, 2014).

The comparison between the policy and climate scenarios presented in this study shows the economic and social tradeoffs among the different policy choices and the challenges that could face the implementation of sustainable groundwater management in Tunisia. The complete restriction of non-renewable groundwater pumping is a challenging and potentially conflictive measure that would likely have a large political cost. Policymakers need to take into account that the success of any water policy intervention largely depends on the cooperation of the affected users that, in this case, would be more prone to accepting the option of substituting overexploited groundwater for subsidized desalinated seawater. Experiences in other regions around the world suggest that it is unlikely that groundwater pumping could be reduced without providing incentives for farmers, such as compensations and subsidies (Madani and Dinar, 2012; Esteban and Albiac, 2012).

As a final remark, the hydro-economic model developed in this study could be improved in future work by including the dynamic aspects of groundwater resources, water quality issues, and environmental damages to groundwater-dependent ecosystems. Additional policy measures could be also evaluated including improved irrigation efficiency, reuse of recycled wastewater for irrigation, artificial aquifer recharge, and groundwater trade.

\section{References}

Abdullah K.B., 2006. Use of water and land for food security and environmental sustainability. Irrigation and Drainage, 55: 219-222, doi:10.1002/ird.254.

Bachta M.S., Elloumi M., 2005. Analyse des politiques hydrauliques en Tunisie : quelques éléments d'évaluation. In: Ceña F., Elloumi M., Gallardo R., Sai M.B., Les défis de la terre : l'agriculture en Espagne et en Tunisie face aux défis de la libéralisation, (s/d). Tunis: Cérès Editions et IRESA.

Benalaya A., Souissi A., Makhlouf M., Ismail Y., Abdelkafi B., Hammami R., Stanbouli T., Chebil A., Ghezal L., Frija A., 2015. Recueil des fiches technico-économique observées des principales cultures pratiquées en Tunisie, Tome 1. Tunis, Tunisie. 
Berbel J., Calatrava J., Garrido A., 2007. Water pricing and irrigation: a review of the European experience. In: Molle F., Berkoff J. (eds.), Irrigation Water Pricing Policy: the Gap between Theory and Practice. Oxon: CAB International, 295-327.

Blanco-Gutiérrez I., Varela-Ortega C., Flichman G., 2010. Cost-effectiveness of groundwater conservation measures: A multi-level analysis with policy implications. Agricultural Water Management, doi:10.1016/j.agwat.2010.10.013.

Carmona G., Varela-Ortega C., Bromley J., 2011. The use of participatory object oriented Bayesian Networks and Agro-Economic models for groundwater management in Spain. Water Resources Management, 25: 1509-1524.

Chebil A., Khemir H., Gaaloul N. and Frija A., 2014. Analyse économique de la recharge artificielle de la nappe souterraine para les eaux usées traitées : cas de Korba. Eaux et Climat au Maghreb, 2: 188-198.

Day R., 1963. On aggregating linear programming models of production. Journal of Farm Economics, 45: 797-813.

Direction Générale du Génie Rural et de l'Exploitation des Eaux (DGGREE), 2012. Données relatives à l'exploitation des eaux dans les périmètres publics irrigués à travers les GDA, résultats d'enquêtes de 2009 à 2010. DGGREE, Tunis.

Easter K.W., Rosegrant M.W., Dinar A., 1999. Formal and informal markets for water: institutions, performance, and constraints. World Bank Research $\mathrm{Ob}$ server, 14(1): 99-116.

Elloumi M., 2016. IWMI Project Report No.7, USAID-funded project "Groundwater governance in the Arab world". IWMI, Cairo.

Esteban E., Albiac J., 2012. The problem of sustainable groundwater management: the case of La Mancha aquifers, Spain. Hydrogeology Journal, 20(5): 851-863.

Esteban E., Dinar A., 2013. Modeling sustainable groundwater management: Packaging and sequencing of policy interventions. Journal of Environmental Management, 119: 93-102.

Faysse N., Hartani T., Frija A., Marlet S., Tazekrit I., 2011. Agricultural use of groundwater and management initiatives in the Maghreb: challenges and opportunities for sustainable aquifer exploitation. Economic Brief. African Development Bank, Tunis.

Fragoso R.M., Marques C., 2015. Alternative irrigation water pricing policies: An Econometric Mathematical Programming Model. New Medit, 14(4): 42-49.

Frija A., Dhehibi B., Chebil A., Villholth K.G., 2015. Performance evaluation of groundwater management instruments: The case of irrigation sector in
Tunisia. Groundwater for Sustainable Development, 1: 23-32.

Garrido A., Calatrava J., 2010. Agricultural Water Pricing: EU and Mexico. Consultant report. Reference [COM/TAD/CA/ENV/EPOC/RD(2008)49]. OECD, Paris, France.

Ghaffour N., Missimer T.M. and Amy G.L., 2013. Technical review and evaluation of the economics of water desalination: Current and future challenges for better water supply sustainability. Desalination, 309: 197-207.

Ghazouani W., Mekki I., 2016. Les ressources en eaux souterraines de la plaine de Haouaria: Etat fragile, acteurs multiples et nécessité d'un changement intégré, IWMI Project Report No. 8, USAID-funded project "Groundwater governance in the Arab world". IWMI, Cairo.

Howitt R., 1995. Positive mathematical programming. American Journal of Agricultural Economics, 77: 329-342.

Institut National de la Météorologie (INM), 2005. Tableau climatiques mensuels. Archive INM pour la période de 1985-2005, Station Nabeul. INM, Tunis.

Institut Tunisienne des Etudes Stratégiques (ITES), 2014. Étude stratégique : Système hydraulique de la Tunisie à l'horizon 2030. ITES, Tunis.

Intergovernmental Panel on Climate Change (IPCC), 2014. Climate Change 2014: impacts, adaptation, and vulnerability. Contribution of working groups II to the fifth assessment report of the IPCC. IPCC, Geneva.

Johansson R.C., Tsur Y., Roe T.L., Doukkali R., Dinar A., 2002. Pricing irrigation water: A review of theory and practice. Water Policy, 4: 173-199.

Kahil M.T., Dinar A. and Albiac J., 2015a. Modeling water scarcity and droughts for policy adaptation to climate change in arid and semiarid regions. Journal of Hydrology, 522: 95-109. https://doi. org/10.1016/j.jhydrol.2014.12.042.

Kahil M.T., Connor J.D. and Albiac J., 2015b. Efficient water management policies for irrigation adaptation to climate change in Southern Europe. Ecological Economics, 120: 226-233. https://doi. org/10.1016/j.ecolecon.2015.11.004.

Kahil M.T., Ward F.A., Albiac J., Eggleston J., Sanz D., 2016a. Hydro-economic modeling with aquifer-river interactions to guide sustainable basin management. Journal of Hydrology, 539: 510-524. http://dx.doi.org/10.1016/j.jhydrol.2016.05.057.

Kahil M.T., Albiac J., Dinar A., Calvo E., Esteban E., Avella L., Garcia-Molla M., 2016b. Improving the performance of water policies: evidence 
from drought in Spain. Water, 8(34). http://dx.doi. org/10.3390/w8020034.

Konikow L., 2011. Contribution of global groundwater depletion since 1900 to sea level rise. Geophysical Research Letters, 38, L17401.

Koundouri P., 2004. Current issues in the economics of groundwater resource management. Journal of Economic Surveys, 18(5): 703-740.

Madani K., Dinar A., 2012. Cooperative institutions for sustainable common pool resource management: Application to groundwater. Water Resources Research, 48(9): W09553.

Mahdi N., Sghaier M., 2017. Essais de réglementation des prélèvements agricoles en eau souterraine dans un contexte d'asymétrie d'information : cas des périmètres publics irrigués, Sud-Est Tunisien. New Medit, 16(3): 64-72.

Martínez-Granados D., Calatrava J., 2014. The role of desalinisation to address aquifer overdraft in SE Spain. Journal of Environmental Management, 144: 247-257.

Molle F., 2009. Water scarcity, prices and quotas: A review of evidence on irrigation volumetric pricing. Irrigation and Drainage Systems, 23: 43-58.

Önal H., McCarl B., 1991. Exact aggregation in mathematical programming sector models. Canadian Journal of Agricultural Economics, 39: 319-334.

Perry C.J. and Hellegers P.J., 2012. To what extent do improved irrigation technologies extend aquifer life? Hydrogeology Journal, 20: 907-913.

Pfeiffer L., Lin C., 2014. Does efficient irrigation technology lead to reduced Groundwater extraction? Empirical evidence. Journal of Environmental Economics and Management, 67(2): 189-208.

Scardigno A., El Chami D., Khadra R., 2014. Equity for an integrated water resources management of irrigation systems in the Mediterranean: the case study of South Lebanon. New Medit, 13(4): 39-45.
Shiklomanov I.A., 2000. World water resources and water use: Present assessment and outlook for 2025, in World Water Scenarios Analyses, edited by F.R. Rijsberman. London: Earthscan.

Skurray J.H. and Pannell D.J., 2012. Potential approaches to the management of third-party impacts from groundwater transfers. Hydrogeology Journal, 20: 879-891.

Sorensen A., Herbertsson T.T., 1998. Policy rules for exploitation of renewable resources: a macroeconomic perspective. Environmental and Resource Economics, 12(1): 53-76.

Tunis International Center for Environmental Technologies (TICET), 2009. Institutional framework and decision making practices for water management in Tunisia. Project Report of the CITET, March 2009. TICET, Tunis.

Wada Y., Van Beek L.P.H., Bierkens M.F.P., 2012. Nonsustainable groundwater sustaining irrigation: A global assessment. Water Resources Research, 48(1), W00L06.

Wheeler S., Bjornlund H., Shanahan M., Zuo A., 2008. Price elasticity of water allocations demand in the Goulburn-Murray Irrigation District. Australian Journal of Agricultural and Resource Economics, 52: 37-56.

World Bank (WB), 2014. Renewable internal freshwater resources per capita. World Bank Database. http:// data.worldbank.org/indicator/ER.H2O.INTR.PC.

Zekri S., 2008. Using economic incentives and regulations to reduce seawater intrusion in the Batinah Coastal area of Oman. Agricultural Water Management, 95(3): 243-252.

Zekri S., Ahmed M., Chaieb R. and Ghaffour N., 2014. Managed aquifer recharge using quaternary-treated wastewater: an economic perspective. International Journal of Water Resources Development, 30(2): 246-261, DOI:10.1080/07900627.2013.837370. 